УДК 811.161.1:001.895:37.091.33

DOI: $10.21779 / 2542-0313-2020-35-3-71-75$

\title{
С.Д. Китляева
}

\section{Инновационные технологии в обучении иностранных слушателей русскому языку}

Калмыцкий государственный университет им. Б.Б. Городовикова; Россия, 358000, Республика Калмыкия, 2. Элиста, ул. Пушкина, 11, корп. 1A; Svetamar08@yandex.ru

В статье освещается проблема преподавания русского языка иностранным гражданам. Рассматриваются вопросы, связанные с формированием и развитием у слушателей иноязычной коммуникативной компетенции. Реализация указанной цели обучения оказывает непосредственное влияние на содержание обучения и отбор образовательных технологий, способствующих повышению результативности обучения русскому языку. Особое внимание уделено сочетанию традиционных методов обучения с инновациями. Инновационные технологии обучения иностранцев русскому языку нацелены на усвоение слушателями учебного материала через практику общения. В статье рассматриваются трудности в освоении морфологии, лексики, фонетики. Анализируются апробированные автором наиболее продуктивные методы и способы работы, дающие определенные результаты. Доказывается, что результативность обучения иностранцев во многом зависит от интегрирования разных видов заданий. Приобретенные ими практические навыки и умения могут быть полезны не только в процессе изучения русского языка, но и в процессе их социального и профессионального взаимодействия.

Ключевые слова: русский язык, иностранные граждане, интеграџия, довузовская подготовка, культура, эффективность, дидактические ресурсы.

Образовательное пространство современного вуза меняет свои количественные и качественные характеристики согласно потребностям времени. Расширение международных связей и увеличение количества иностранных граждан, желающих получить образование именно в Калмыцком государственном университете, привело к необходимости усвоения опыта, накопленного ведущими вузами страны в плане преподавания русского языка как иностранного и создания собственных дидактических ресурсов. Русский язык должен стать инструментом общения, позволяющим проникнуть в другую культуру, определить для себя ее характерные черты и усвоить тип поведения, адекватного восприятию представителями другой культуры. Необходимо показать особенности культур и найти общее в них. Только осознав это, будущие студенты смогут стать полноценными участниками межкультурного диалога.

На факультете довузовской подготовки и обучения иностранных граждан занятия проводятся в группах по 12-16 человек, различающихся по своим психологическим характеристикам, религиозным верованиям, возрастом и средой воспитания. Именно в этом заключается еще одна проблема, которая требует поиска таких методов обучения, которые позволили бы наиболее полно реализовать природные способности будущих студентов, развивать их, давать им знания в той области, какую они выбрали. Главными принципами в достижении такой педагогической задачи становятся проблема выбора методов обучения русскому языку как иностранному и проверка их эффективности. 
Как правило, после окончания факультета довузовской подготовки слушатель попадает в русскоязычную среду на равных правах со всеми студентами университета, где его окружают русскоговорящие одногруппники, где все предметы преподаются на русском языке, что требует от него хорошей языковой подготовки. В этой связи преподавателей, которые обучают иностранных граждан, волнует вопрос, как быстрее, эффективнее, разнообразнее и интереснее подать иностранным слушателям учебный материал. Для того чтобы решить эту нелегкую задачу, преподаватели-практики учебных заведений различного профиля в России и за рубежом разрабатывают новые методы, приемы, формы обучения русскому языку как иностранному, создают новые концепции. Их опыт, научные и учебно-методические наработки помогают решить актуальные вопросы, связанные с преподаванием русского языка в высших учебных заведениях РФ. Преподаватели-языковеды кафедры русского языка как иностранного и общегуманитарных дисциплин КалмГУ постоянно следят за новинками в этой области, выезжают на курсы, семинары, конференции, стажировки, посещают специализированные вебинары, где совместно с коллегами из других вузов учатся решать эти проблемы. Важной предпосылкой успешного учебного процесса является выработка четких методических основ, принципов преподавания русского языка как иностранного. Несмотря на множество разработанных форм и методов, мы пытаемся найти то среднее, которое отвечает требованиям к усвоению русского языка.

В силу больших технологических возможностей современное поколение с раннего детства привыкает к мобильным телефонам, мониторам, где дается изображение действа (мультфильмы, видеозаписи, комиксы и др.), т. е. привыкают к зрительной составляющей коммуникации. Слушающий видит говорящего, наблюдает за его артикуляцией, его собственные органы речи как бы сами собой укладываются аналогичным образом, ему легче узнать слышимые звуки, слова, выражения и воспроизвести их во внутренней речи [5]. Поэтому в своей работе наряду с другими методами и формами мы используем и элементы метода инновационных технологий. Именно использование инновационных технологий обучения иностранным языкам даёт слушателям-иностранцам дополнительные стимулы для развития мышления, также формирует у них необходимые умения. В инновационных технологиях используется мультимедийная программа, которая заключается в следующем: использование видеороликов с текстовой поддержкой; запись разговора носителя языка, возможность для обучающегося стать собеседником, неким третьим лицом, проконтролировать качество иноязычного общения; возможность не только слышать, но и видеть носителей языка, видеть их жесты и артикуляцию. При этом меняется парадигма обучения, больше внимания уделяется формированию навыков и умений самостоятельно приобретать знания в условиях исследовательской деятельности [2;8].

Скорость речи на занятиях также является помехой для понимания. При быстром темпе речи меняется качество звуков, искажается звучание, безударные гласные редуцируются, иногда совсем «проглатываются»; части слов, фразы приобретают непривычный оттенок.

Иногда, находясь далеко от говорящего, мы хуже слышим его не только из-за ослабления звука, но и потому, что не можем разглядеть артикуляцию. По телефону или по радио иностранная речь воспринимается с большим трудом. Об этом говорит и опыт кураторства, когда необходимо передать какую-то информацию, а слушатель в самые первые дни пребывания в нашей стране просто не может отвечать или передаёт трубку друзьям и знакомым, которые лучше понимают русский язык. Поэтому кураторы пишут им развернутое сообщение, чтобы напомнить, например, что завтра с утра 
надо сдать кровь, но сделать это необходимо на пустой желудок и т. п. Человеку, впервые оказавшемуся в другой языковой среде, трудно воспринимать речь, действия людей, говорящих на непонятном ему языке.

Зрительной опорой мог бы служить и графический образ слышимого слова, прочно усвоенный учащимися, но из-за большого расхождения в написании и произношении эффект от такой зрительной опоры бывает обратным. Под влиянием графического образа искажается звуковой образ (или просто такая связь не устанавливается), и слушатель не узнает на слух знакомое по письменным текстам слово [7]. Для преодоления этих трудностей используются видео-упражнения, позволяющие отработать лексику по определенной теме. В подобных упражнениях совмещены зрительный образ объекта и произношение его письменного образа.

Необходимо уделить внимание выработке умения постановки ударения и интонационного оформления собственных мыслей в соответствии с законами русского языка. Практика показывает, что ошибки в определении места ударения в речи весьма распространены и стабильны. Это связано с тем, что в русском языке ударение нефиксированное, у него нет постоянного места в слове на каком-либо слоге, в то время как для носителей большинства иностранных языков привычной является постановка ударения на одном определенном слоге. Из этого следует, что работа с фонетикой должна обязательно включать работу над ударением (и словесным, и логическим) [10]. Передавая слушателям сведения о специфике русского ударения, на определенных примерах важно показать следующее: а) ударный слог необходимо произносить с большей силой, б) ударный гласный характеризуется долготой, длительностью; в) ударный слог отличается значительной напряженностью произносительного аппарата и характеризуется усилением выдоха [6].

Раздел «Лексика» следует изучать с учетом сходств и различий в количестве значений слов в родном и русском языках, подразделяемых на группы: а) слова, совпадающие по смыслу в родном и русском языках; б) русские многозначные слова, которым в родном языке обучающегося соответствуют однозначные; в) многозначные слова родного языка, которым в русском языке соответствуют однозначные; г) русские слова, которым в родном языке соответствуют словосочетания; д) слова родного языка, которым в русском соответствуют словосочетания.

При изучении темы «Морфология» необходимо обратить внимание на те явления русского языка, которых нет в родных языках обучающихся. К грамматическим категориям, отсутствующим в родных языках слушателей и вызывающим сложности, относятся: а) наличие в русском языке категории рода существительных и её отсутствие в родных языках; б) несовпадение падежной системы русского и родных языков; в) наличие в русском языке предлогов и их отсутствие в родных; г) противопоставление глаголов совершенного и несовершенного вида в русском языке и отсутствие такого противопоставления во многих родных языках; д) различия в категориях одушевленности и неодушевленности существительных в русском и родных языках $[4 ; 5]$.

Вызывают определенные затруднения глаголы движения, которые обозначают различные типы движения: идти - однонаправленное движение в определенное время (часто - в момент речи), ходить - разнонаправленное движение и не в момент речи ( $я$ иду домой, я часто хожу после занятий в парк) и др. [9].

При изучении темы «Части речи» обучающиеся в первую очередь должны научиться характеризовать род существительного по признаку биологического пола лица (семантический признак), падежным окончаниям (морфологические признаки), а также по согласовательным признакам в предложении (синтаксические характерис- 
тики) [3]. Особые сложности в освоении этой темы вызывает выделение рода существительных по морфологическим и синтаксическим характеристикам. Усвоению этой темы в определенной степени может помочь повторение пройденного материала по словообразованию, в частности суффиксов существительных мужского и женского рода (-тель, -ик; -ица, -ка).

Трудно усваиваются категории одушевленности и неодушевленности существительных, поскольку в родных языках на вопрос кто?, как правило, отвечают слова, означающие человека, а слова, означающие различных животных, могут отвечать на вопрос что? [10].

При изучении темы «Синтаксис» необходимо выделить вопросы согласования и управления в словосочетании, синонимии односоставных и двусоставных конструкций, а также простых предложений с обособленными членами и сложноподчиненных предложений, обратить внимание на порядок слов в предложении. Их освоение вызывает серьезные трудности. При изучении разных типов простого предложения необходимо понимать, что в русском языке продуктивность их употребления неодинакова. Из односоставных предложений максимальную частотность употребления имеют безличные конструкции, которым в родных языках слушателей часто соответствуют двусоставные предложения [1; 4].

Таким образом, основной причиной ошибок является языковое и культурное своеобразие русского языка. В первые месяцы пребывания в нашей стране слушателям, носителям другой культуры и другого языка, тяжело преодолеть барьер и выйти за пределы привычного, знакомого мироощущения. Естественно, что они не могут в полной мере понимать, чувствовать слово, быстро, выбрать соответствующие правила, подбирать правильные слова и выражения. Тем не менее, эти сложности вполне преодолимы, и использование современных технологий позволяет интенсифицировать процесс обучения русскому языку иностранных учащихся.

\section{Литература}

1. Васильева Г.М., Левина И.Н. Лексико-синтаксический словарь сложноподчиненных предложений для иностранных студентов: теоретические и методические ориентиры // Вопр. лексикографии. - 2017. - № 12. - С. 5-23.

2. Павлова Е.В., Кобзева Н.А., Овчинникова И.С. Инновационные методики обучения иностранным языкам // Молодой ученый. - 2015. - № 12. - С. 790-792.

3. Стародумов И.В. Особенности преподавания русского языка как иностранного // Молодой ученый. - 2018. - № 40. - С. 204-207.

4. Степаненко В.А., Нахабина М.М., Курлова И.В. Современные подходы к методике преподавания русского языка как иностранного. Полилингвиальность и транскультурные практики РУДН. - М., 2013. - С. 175-181.

5. Хамеед A.A. Проблемы и особенности преподавания русского языка как иностранного // Научный форум: филология, искусствоведение и культурология. Сб. ст. по материалам XIV Международной научно-практической конференции. № 3 (14). - М.: МЦНО, 2018. - С. 118-127.

6. Китляева С.Д., Китляева М.А. Инновационные подходы к обучению русского языка как иностранного // Материалы V Республиканской научно-практической конференции учащихся и студентов образовательных организаций «Диалог культур народов - залог мира и согласия». - Городовиковск, 2019. 
7. Ковалькова М.В., Николаева Т.В., Зайщева В.М. Метод проектов как фактор формирования иноязычной компетентности // Общество. Экономика. Культура: актуальные проблемы, практика решения. Сборник научных статей. - Барнаул, 2015. $250 \mathrm{c}$.

8. Пашаева К.Г.-Г. К вопросу обучения русскому языку как иностранному с помощью средств информационно-коммуникационных технологий // Вестник Московского государственного областного университета. Сер.: Педагогика. - 2017. - № 3. C. 113-119.

9. Седеньо М.Ю. Мультимедиа технологии как средство интенсификации обучения русскому языку как иностранному при коммуникативном подходе // Научное сообщество студентов XXI столетия. Гуманитарные науки: сб. ст. по мат. XXXIX Межд. студ. науч. практ. конф. - 2016. - № 2 (39) [Электронный ресурс].

10. Ядав Р., Нестерова Н.Г., Верма К.С. Принципы определения лексического минимума для программы обучения русскому языку иностранцев как проблеме учебной лексикографии // Вопросы лексикографии. - 2017. - № 12. - С. 106-124.

Поступила в редакциию 5 сентября 2020 г.

UDC 811.161.1:001.895:37.091.33

DOI: $10.21779 / 2542-0313-2020-35-3-71-75$

\section{Innovative Technologies in Training Foreign Listeners in the Russian Language}

\section{S.D. Kitlyaeva}

Kalmyk State University named after B.B. Gorodovikov; Russia, 358000, Elista, Pushkinst., 11; Svetamar08@yandex.ru

The article highlights the problem of teaching Russian to foreign citizens. The issues related to the formation and development of foreign language communicative competence among students are considered. The implementation of this learning goal has a direct impact on the content of education and the selection of educational technologies that contribute to improving the effectiveness of teaching the Russian language. Particular attention should be paid to combining traditional teaching methods with innovation. Innovative technologies for teaching foreigners the Russian language are aimed at the assimilation of educational material by students through the practice of communication. The article also examines and lists difficulties in different linguistic categories: in morphology, vocabulary, phonetics. The work analyzes the most productive methods and ways of work approved by the author, which give good results. It is proved that the effectiveness of foreigners learning complex grammatical topics largely depends on the integration of different types of tasks. The practical skills and abilities they have acquired can be useful not only in the process of learning the Russian language, but also in the process of their social and professional interaction.

Keywords: Russian language, foreign citizens, integration, pre-university training, culture, efficiency, didactic resources.

Received 5 September, 2020 